\title{
Analisis penerapan sapta pesona dalam meningkatkan kesejahteraan masyarakat (studi pada desa Watukarung, kecamatan Pringkuku, kabupaten Pacitan)
}

\author{
Nur Wahid Ramadhan*, Nasikh \\ Universitas Negeri Malang, Jl. Semarang No. 5 Malang, Jawa Timur, Indonesia \\ *Penulis korespondensi, Surel: agung.nugroho150798@gmail.com
}

Paper received: 2-2-2021; revised: 20-2-2021; accepted: 27-2-2021

\begin{abstract}
Abstrak
Tujuan dari penelitian ini adalah untuk menganalisis penerapan prinsip Sapta Pesona dalam mengembangkan potensi wisata lokal dalam upaya untuk meningkatkan kesejahteraan masyarakat di Desa Watukarung. Penelitian ini menggunakan pendekatan deskriptif kualitatif untuk memperoleh data secara menyeluruh tentang penerapan prinsip ekowisata yang ada di Desa Watukarung. Wawancara ditujukan kepada informan yaitu kepala desa, anggota pokdarwis, serta masyarakat lokal, dan dokumentasi berupa foto guna pendukung penelitian. Tahap-tahap yang dilakukan dalam penelitian ini dimulai dari tahap pengumpulan data, tahap reduksi data, tahap penyajian data, dan tahap penarikan kesimpulan. Hasil penelitian menunjukkan bahwa dalam penerapan Sapta Pesona di Desa Watukarung sudah berjalan cukup baik, dengan tingkat sadar wisata dari masyarakat di Desa Watukarung yang sudah dengan baik. Terbukti dengan partisipasi dari masyarakat dari Desa Watukarung yang antusias ikut serta dalam proses pengembangan wisata di Desa Watukarung. Setiap prinsip dari Sapta Pesona seperti aman, tertib, sejuk, indah, ramah, dan kenangan sebagian besar sudah di lakukan oleh masyarakat di Desa Watukarung. Tapi memang ada bagian yang masih bisa dimaksimalkan lagi oleh masyarakat. Belum tersedianya cinderamata khas dari Desa Watukarung menjadi kekurangan yang menjadi peluang bagi masyarakat sendiri untuk bisa dimaksimalkan sehingga mampu menjadi sumber tambahan penghasilan lagi bagi masyarakat Desa Watukarung. Berkembangnya wisata di Desa Watukarung memberikan banyak peluang usaha baru bagi masyarakat yang ingin ikut terlibat langsung. Pembukaan tempat wisata baru seperti wisata Pantai Kasap dan Sungai Cokel memberikan pilihan sumber penghasilan lain bagi masyarakat yang dulunya hanya berfokus mengandalkan hasil laut dan pertanian sebagai nelayan dan petani. Dampak Sapta Pesona kepada kesejahteraan masyarakat di Desa Watukarung dirasa cukup positif, walaupun memang hanya masyarakat yang terlibat langsung saja di dalam proses pengembangan obyek wisata. Selain itu, pembukaan area wisata baru juga berdampak kepada pengurangan jumlah penganguran dikarenakan pemuda yang ikut serta berpartisipasi dalam pengembangan wisata. Masih banyak potensi wisata yang bisa dimaksimalkan lagi di Desa Watukarung, yang selama ini masih terkendala akses menuju obyek wisata tersebut. Diharapkan Sapta Pesona tetap menjadi acuan bagi masyarakat untuk mengembangkan potensi wisata di daerahnya, sehingga tetap memperhatikan kelestarian lingkungan yang juga menjadi perhatian dari Sapta Pesona.
\end{abstract}

Kata kunci: sapta pesona; kesejahteraan; partisipasi masyarakat

\section{Pendahuluan}

Indonesia saat ini masih dikategorikan sebagai negara berkembang, dengan jumlah populasi penduduk melebihi 200 juta jiwa yang terbentang dari sabang sampai merauke, yang terdiri dari berbagai ras, agama dan budaya. Indonesia juga memiliki kekayaan alam yang sangat melimpah dengan berbagai potensi yang perlu ditingkatkan, untuk itu perlu perlu dilakukannya pembangunan untuk memaksimalkan potensi yang ada di Indonesia. Pembangunan di sektor pariwisata juga termasuk yang perlu diperhatikan. Sektor pariwisata Indonesia mempunyai potensi yang cukup besar untuk terus di kembangkan. Sebagai negara kepulauan, Indonesia memiliki 17.504 pulau yang masuk dalam wilayah kedaulatan Negara

This work is licensed under a Creative Commons Attribution-ShareAlike 4.0 International License. 
Kesatuan Republik Indonesia, dengan setiap potensi yang dimiliki tiap pulau. Dilatarbelakangi oleh keindahan alam dan keanekaragaman budaya, menjadikan negara Indonesia sebagai negara yang terkenal akan objek wisata, baik itu objek wisata alam maupun objek wisata budaya.

Kabupaten Pacitan memiliki 12 dua belas wilayah kecamatan, antara lain Kecamatan Donorojo, Kecamatan Punung, Kecamatan Pringkuku, Kecamatan Pacitan, Kecamatan Kebonagung, Kecamatan Arjosari, Kecamatan Nawangan, Kecamatan Bandar, Kecamatan Tegalombo, Kecamatan Tulakan, Kecamatan Ngadirojo dan Kecamatan Sudimoro. Di Setiap kecamatan memiliki beberapa objek wisata andalan yang menarik dan layak untuk dikunjungi oleh wisatawan. Adapun wisata alam pantai yang berada di kabupaten Pacitan antara lain Pantai Teleng Ria (di Kecamatan Pacitan), Pantai Bawur, Pantai Sidomulyo (di Kecamatan Ngadirojo), Pantai Jetak, Pantai Wawaran, Pantai Bakung (di Kecamatan Tulakan), Pantai Klayar (di Kecamatan Donorojo), Pantai Srau dan Pantai Watu Karung (di Kecamatan Pringkuku). Salah satu objek wisata alam pantai yang bertaraf internasional dan memiliki fasilitas yang memadai adalah Pantai Teleng Ria. Selain itu masih banyak objek wisata alam pantai lainya yang belum dikembangkan lebih lanjut yang memiliki potensi dan daya tarik tersendiri agar dapat menarik wisatawan untuk mengunjunginya (Disparta Kabupaten Pacitan Tahun 2017).

Keberhasilan pembangunan dan pengembangan pariwisata juga tidak terlepas dari adanya kapasitas sumber daya manusia. Sumber daya manusia dalam bidang pariwisata ini, yaitu pemerintah, swasta dan masyarakat. Ketiga sumber daya manusia tersebut merupakan pemangku kepentingan yang memiliki peran penting dalam mewujudkan cita-cita pembangunan pariwisata. Dengan sinergi dan koordinasi yang baik antara pemerintah, swasta dan masyarakat sejak dalam proses perencanaan, pelaksanaan, pemantauan, dan evaluasi pembangunan pariwisata maka keberhasilan pengembangan pariwisata akan meningkat. Keterlibatan pemerintah, swasta dan masyarakat dalam pengembangan pariwisata akan membawa tuntutan bagi partisipasi masyarakat. Hal ini tentunya perlu ditumbuhkan pemahaman atau persepsi yang sama dari stakeholders terkait dengan pemberian ruang yang seluas-luasnya bagi masyarakat sebagai pelaku utama pengembangan pariwisata.

Sapta Pesona merupakan jabaran konsep Sadar Wisata yang terkait dengan dukungan dan peran masyarakat sebagai tuan rumah dalam upaya untuk menciptakan lingkungan dan suasana kondusif yang mampu mendorong tumbuh dan berkembangnya industri pariwisata yang berdasarkan Keputusan Menteri Pariwisata, Pos dan Telekomunikasi Nomor : KM.5/UM.209/MPPT-89 tentang Pedoman Penyelenggaraan Sapta Pesona dilambangkan seperti Matahari bersinar sebanyak tujuh unsur yang terdiri atas unsur keamanan, ketertiban, kebersihan, kesejukan, keindahan, keramahan dan kenangan. Program Sapta Pesona ini juga diterapkan di Kabupaten Pacitan, dengan diterapkannya program ini di Kabupaten Pacitan diharapkan masyarakat di Kabupaten Pacitan mampu memiliki tingkat sadar wisata yang tinggi. Sehingga potensi yang ada di Kabupaten Pacitan dapat dioptimalkan dengan baik. Banyak dampak positif yang bisa dihasilkan dari masyarakat yang memiliki tingkat sadar wisata yang tinggi, diantaranya adalah kesejahteraan masyarakat yang akan meningkat. Tempat wisata yang diolah dengan sedemikian pula tentunya akan memiliki daya tarik lebih bagi para wisatawan yang akan berkunjung, hal tersebut juga pasti akan diikuti dengan pendapatan masyarakat yang akan meningkat dan kesejahteraan yang akan juga meningkat. 
Desa Watukarung menjadi salah satu desa yang ada di Pacitan yang memiliki potensi dari segi pariwisata yang cukup tinggi. Pantai Watukarung menjadi salah satu tempat yang ramai dikunjungi oleh para wisatawan, hal ini perlu adanya daya dukung berupa kerjasama yang sistematis dan berkelanjutan dari pihak pemerintah, swasta dan masyarakat sekitar. Karena idealnya pengembangan wisata harus melibatkan partisipasi dan peran serta masyarakat setempat secara aktif di dalamnya. Pengelolaan potensi wisata Watukarung melalui Pokdarwis sebagai penggerak masyarakat diharapkan dapat memberikan pemahaman kepada masyarakat tentang Sapta Pesona sehingga menjadi acuan bagi masyarakat untuk mengembangkan wisata lokal di Desa Watukarung. Dengan berkembangnya pariwisata lokal diharapkan menunjang ekonomi masyarakat luas, khususnya masyarakat asli (indigenous people) setempat yang berada disekitar lokasi/ obyek wisata. Dengan melihat permasalahan yang terjadi diatas maka peneliti tertarik untuk meneliti tentang "Analisis Penerapan Sapta Pesona Dalam Menciptakan Masyarakat Sadar Wisata Untuk Meningkatkan Kesejahteraan Masyarakat (Studi Pada Desa Watukarung, Kecamatan Pringkuku, Kabupaten Pacitan)"

Masalah dan fokus penelitian dipandu pertanyaan berikut: "Bagaimana penerapan Sapta Pesona dan dampak kepada Kesejahteraan Masyarakat di Desa Watukarung?" Pertanyaan di atas dapat dipilah ke dalam sub pertanyaan (1) Bagaimana penerapan Sapta Pesona di Desa Watukarung? (2) Bagaimana kesejahteraan masyarakat di Desa Watukarung setelah adanya penerapan Sapta Pesona?

\subsection{Pariwisata}

Organisasi pariwisata dunia, UNWTO, mendefinisikan pariwisata sebagai aktivitas perjalanan dan tinggal seseorang di luar tempat tinggal dan lingkungannya selama tidak lebih dari satu tahun berurutan untuk berwisata, bisnis, atau tujuan lain dengan tidak untuk bekerja di tempat yang dikunjunginya tersebut. Menurut Hunzieker dan Krapf dalam Soekadijo (2000:12), pariwisata dapat didefinisikan sebagai keseluruhan jaringan dan gejala-gejala yang berkaitan dengan tinggalnya orang asing di suatu tempat, dengan syarat bahwa mereka tidak tinggal disitu untuk melakukan suatu pekerjaan yang penting yang memberikan keuntungan yang bersifat permanen maupun sementara.

\subsection{Partisipasi}

Dr. Made Pidarta dalam Siti Irene A.D. (2015: 50) mengatakan bahwa partisipasi adalah pelibatan seseorang atau beberapa orang dalam suatu kegiatan. Keterlibatan dapat berupa keterlibatan mental dan emosi serta fisik dalam menggunakan segala kemampuan yang dimilikinya (berinisiatif) dalam segala kegiatan yang dilaksnakan serta mendukung pencapaian tujuan dan tanggungjawab atas segala keterlibatan. Partisipasi adalah keikutsertaan individu atau sekelompok individu dalam suatu kegiatan. Partisipasi merupakan proses yang akan menciptakan jaringan sosial baru yang masing-masing berusaha untuk melaksanakan tahapantahapan kegiatan demi tercapainya tujuan akhir yang diinginkan (Aprillia Theresia, dkk, 2014: 196-197).

\subsection{Sapta Pesona}

Menurut Amirullah (2016) Jabaran dari masing-masing unsur Sapta Pesona tersebut adalah sebagai berikut: (1) Aman yaitu suatu kondisi lingkungan di destinasi pariwisata atau 
daerah tujuan wisata yang memberikan rasa tenang, bebas dari rasa takut dan kecemasan bagi wisatawan dalam melakukan perjalanan atau kunjungan ke daerah tersebut. (2) Tertib yaitu suatu kondisi lingkungan dan pelayanan di destinasi pariwisata atau daerah tujuan wisata yang mencerminkan sikap disiplin yang tinggi serta kualitas fisik dan layanan yang konsisten dan teratur serta efisien sehingga memberikan rasa nyaman dan kepastian bagi wisatawan dalam melakukan perjalanan atau kunjungan ke daerah tersebut. (3) Bersih yaitu suatu kondisi lingkungan serta kualitas produk dan pelayanan di destinasi pariwisata atau daerah tujuan wisata yang mencerminkan keadaan yang sehat/ higienis sehingga memberikan rasa nyaman dan senang bagi wisatawan dalam melakukan perjalanan atau kunjungan ke daerah tersebut. (4) Sejuk yaitu suatu kondisi lingkungan di destinasi pariwisata atau daerah tujuan wisata yang mencerminkan keadaan yang sejuk dan teduh yang akan memberikan perasaan nyaman dan "betah" bagi wisatawan dalam melakukan perjalanan atau kunjungan ke daerah tersebut. (5) Indah yaitu suatu kondisi lingkungan di destinasi pariwisata atau daerah tujuan wisata yang mencerminkan keadaan yang indah dan menarik yang akan memberikan rasa kagum dan kesan yang mendalam bagi wisatawan dalam melakukan perjalanan atau kunjungan ke daerah tersebut, sehingga mewujudkan potensi kunjungan ulang serta mendorong promosi ke pasar wisatawan yang lebih luas. (6) Ramah yaitu suatu kondisi lingkungan yang bersumber dari sikap masyarakat di destinasi pariwisata atau daerah tujuan wisata yang mencerminkan suasana yang akrab, terbuka dan penerimaan yang tinggi yang akan memberikan perasaan nyaman, perasaan diterima dan "betah" (seperti di rumah sendiri) bagi wisatawan dalam melakukan perjalanan atau kunjungan ke daerah tersebut. (7) Kenangan yaitu suatu bentuk pengalaman yang berkesan di destinasi pariwisata atau daerah tujuan wisata yang akan memberikan rasa senang dan kenangan indah yang membekas bagi wisatawan dalam melakukan perjalanan atau kunjungan ke daerah tersebut.

\subsection{Sadar Wisata}

Sadar Wisata, adalah suatu kondisi yang menggambarkan partisipasi dan dukungan segenap komponen masyarakat dalam mendorong terwujudnya iklim yang kondusif bagi tumbuh dan berkembangnya kepariwisataan di suatu destinasi atau wilayah.

Dalam hal ini digambarkan sebagai bentuk kesadaran masyarakat untuk berperan aktif dalam 2 (dua) hal berikut, yaitu: (1) Masyarakat menyadari peran dan tanggung jawabnya sebagai tuan rumah (host) yang baik bagi tamu atau wisatawan yang berkunjung untuk mewujudkan lingkungan dan suasana yang kondusif sebagaimana tertuang dalam slogan Sapta Pesona. (2) Masyarakat menyadari hak dan kebutuhannya untuk menjadi pelaku wisata atau wisatawan untuk melakukan perjalanan ke suatu daerah tujuan wisata, sebagai wujud kebutuhan dasar untuk berekreasi maupun khususnya dalam mengenal dan mencintai tanah air.

\subsection{Kesejahteraan Masyarakat}

Menurut Nasikun (1996) konsep kesejahteraan dapat dirumuskan sebagai padanan makna dari konsep martabat manusia yang dapat dilihat dari empat indikator yaitu: rasa aman (security), kesejahteraan (welfare), kebebasan (freedom), dan jati diri (identity). Setiap individu membutuhkan kondisi yang sejahtera, baik sejahtera dalam hal materil dan dalam hal non materil sehingga dapat terciptanya suasana yang harmonis dalam bermasyarakat. 


\section{Metode}

Jenis penelitian yang digunakan yaitu penelitian kualitatif dengan mendeskripsikan dan menganalisis tentang penerapan Sapta Pesona yang ada di Desa Watukarung dan dampak terhadap kesejahteraan masyarakat di Desa Watukarung. Teknik pengumpulan data dalam penelitian ini dilakukan melalui penelitian di lapangan untuk mendapatkan informasi maupun data melalui observasi, wawancara, dan dokumentasi.

\section{Hasil dan Pembahasan}

\subsection{Penerapan Sapta Pesona di Desa Watukarung}

Jabaran dari Sapta Pesona adalah konsep Sadar Wisata yang terkait dengan dukungan dan peran masyarakat sebagai tuan rumah (Pedoman Kelompok Sadar Wisata, 2012). Dari pengertian ini dapat disimpulkan bahwa penerapan Sapta Pesona dibutuhkan kesadaran dari masyarakat akan potensi yang dimiliki di daerahnya. Pada awalnya hanya Pantai Watukarung yang diperhatikan oleh masyarakat di Desa Watukarung. Masyarakat di Desa Watukarung lebih banyak memilih profesi sebagai nelayan dan petani, mengandalkan hasil laut dan pertanian sebagai sumber penghasilan dan penopang kehidupan dari masyarakat Desa Watukarung, hal tersebut dikarenakan memang sumber daya alam yang masih melimpah di kawasan Desa Watukarung. Maka dari itu, masyarakat kurang peduli dengan potensi wisata yang ada di Desa Watukarung. Melalui Pokdarwis yang sudah pernah mengikuti pelatihan dari Pemerintah langsung, memberikan sosialisasi tentang Sapta Pesona kepada masyarakat di Desa Watukarung. Setelah adanya sosialisasi tersebut, secara perlahan anggota pokdarwis memberikan contoh kegiatan yang menunjukan perilaku Sapta Pesona kepada masyarakat, yang akhirnya sampai sekarang masyarakat di Desa Watukarung sudah merasakan dampak dari penerapan Sapta Pesona. Meskipun tidak semua masyarakat desa merasakan dampaknya hanya masyarakat yang terlibat langsung di dalam pengembangan wisata di Desa Watukarung. Adanya dampak atau perubahan dari penerapan Sapta Pesona ini dapat dilihat dari wawancara yang sudah dilakukan dengan beberapa informan dari masyarakat desa. Dari hasil wawancara tersebut digunakan oleh peneliti untuk menyimpulkan dan merumuskan beberapa point terkait hal yang perlu diperhatikan untuk membentuk atau mengamati aksi penerapan Sapta Pesona di Desa Watukarung.

\subsubsection{Aman}

Masyarakat Desa Watukarung menyadari keamanan adalah salah satu faktor penting dalam pengembangan kawasan wisata di Desa Watukarung, maka dari itu masyarakat melakukan beberapa aksi sesuai dengan yang ada di dalam Pedoman Kelompok Sadar Wisata (2012) tentang bentuk aksi yang perlu diwujudkan untuk menciptakan rasa aman antara lain: sikap tidak mengganggu kenyamanan wisatawan dalam kunjungannya, menolong dan melindungi wisatawan, memelihara keamanan lingkungan, dan meminimalisir resiko kecelakaan dalam penggunaan fasilitas publik.

\subsubsection{Tertib}

Tertib menjadi salah satu bagian dari Sapta Pesona yang mengarah kepada perilaku pariwisata yang beretika dan bertanggung jawab baik dari sisi wisatawan maupun pengelola (Stanford, 2016). Ketertiban dari kawasan wisata di Desa Watukarung diterapkan dengan melakukan beberapa bentuk aksi seperti mewujudkan budaya antri, mentaati peraturan yang 
berlaku dan disiplin waktu. Aksi tersebut bertujuan untuk menciptakan kenyamanan dan kepastian kepada wisatawan ketika berkunjung ke kawasan wisata di Desa Watukarung.

\subsubsection{Bersih}

Kebersihan lingkungan kawasan wisata merupakan yang perlu diperhatikan. Dari hasil wawancara dan pengamatan yang sudah dilakukan masalah kebersihan lingkungan menjadi perhatian bagi masyarakat di Desa Watukarung. Sesuai dengan pedoman Kelompok sadar wisata (2012). Penerapan berupa bentuk aksi yang mengarah kepada kondisi bersih bebas dari sampah, kotoran, hama penyakit dan rapi. Dengan memberikan fasilitas pembuangan sampah agar wisatawan tidak membuang sampah sembarangan, hingga mengadakan kegiatan gotong royong membersihkan area wisata di sekitar Desa Watukarung secara rutin setiap jum'at.

\subsubsection{Sejuk}

Menjaga kesejukan suatu destinasi wisata pariwisata dengan beberapa hal yaitu dengan menjaga kondisi sejuk di area publik melalui kegiatan menanam dan memelihara penghijauan di sekitar sesuai dengan aksi yang terdapat dalam Pedoman Kelompok Sadar Wisata (2012). Dari hasil wawancara dan pengamatan yang sudah dilakukan, Desa Watukarung masih menjadi desa asri yang masih dikelilingi perbukitan hijau yang masih memberikan kesejukan yang datang berkunjung. Masyarakat sudah melakukan upaya dengan mengadakan penanaman pohon cemara di sekitar pantai, sehingga menimbulkan kesan sejuk di sekitar pantai yang ada di Desa Watukarung.

\subsubsection{Indah}

Manusia pada hakikatnya selalu membutuhkan keindahan dan harmonisasi keanekaragaman hayati untuk ketenangan jiwa, kesenangan dan kedamaian dalam diri masing-masing (Hakim,2014). Membuat wisatawan betah dan ingin terus kembali ke daerah tujuan wisata merupakan tujuan yang selalu ingin dicapai setiap destinasi wisata. Salah satu caranya adalah menjaga keindahan dan kelestarian lingkungan yang merupakan aset dari daerah tersebut. Maka diperlukan untuk menciptakan lingkungan yang menggambarkan keindahan dan menarik dengan melakukan beberapa aksi seperti menjaga obyek dan daya tarik wisata dalam tatanan estetik, teratur dan menjaga keindahan vegetasi seperti yang sudah tercantum pada Pedoman Kelompok Sadar Wisata (2012). Pantai yang ada di Desa Watukarung terkenal dengan pantai yang menyuguhkan pemandangan pasir putih dan bersih, sehingga dilakukan beberapa untuk menjaga keindahan dari pantai tersebut, yaitu dengan melarang mengadakan atau menyalakan api dan mendirikan tenda untuk bermalam di sekitar pantai. Diharapkan salah satu upaya tersebut dapat melestarikan keindahan dari wisata yang ada di Desa Watukarung.

\subsubsection{Ramah}

Masyarakat sebagai tuan rumah menjadi posisi yang penting untuk menciptakan kondisi yang menyenangkan kepada wisatawan yang datang berkunjung. Keterlibatan atau dukungan masyarakat dalam kegiatan wisata sangat mempengaruhi kunjungan wisatawan. Sikap baik dan ramah yang diberikan masyarakat sebagai tuan rumah akan membuat wisatawan betah tinggal di daerah tujuan wisata (Suwena, 2010). Sapta Pesona sendiri dapat berjalan dengan baik dengan partisipasi penuh dari masyarakat. Dari hasil wawancara yang sudah dilakukan, 
masyarakat Desa Watukarung sudah melakukan beberapa hal untuk menunjukan keramahan sesuai dengan Pedoman Kelompok Sadar Wisata (2012) yaitu bersikap ramah kepada wisatawan yang datang dan meminta bantuan informasi kepada masyarakat serta memberikan pertolongan kepada wisatawan yang membutuhkan bantuan seperti ingin dipandu untuk menyusuri wisata yang ada di Desa Watukarung.

\subsubsection{Kenangan}

Memberikan kenangan bisa dikatakan memberikan pengalaman yang berkesan, dalam hal ini memberikan pengalaman yang berkesan kepada wisatawan yang berkunjung ke kawasan wisata di Desa Watukarung. Kenangan memang perlu diperhatikan karena membantu memberikan kesan yang baik kepada wisatawan yang akan disampaikan ke wisatawan yang lain, sehingga ingin berkunjung kembali ke destinasi wisata yang sudah pernah dikunjungi. Hal ini memang untuk sekarang belum dilakukan secara maksimal oleh masyarakat Desa Watukarung, masih hanya sebatas makanan khas seperti olahan ikan laut bakar dan ikan laut goreng yang saat ini bisa dijadikan oleh-oleh bagi wisatawan yang berkunjung. Diharapkan kedepannya masyarakat dapat menciptakan cinderamata yang khas dari Desa Watukarung sebagai kenangan untuk wisatawan yang sudah berkunjung. Jika maksimalkan maka hal tersebut dapat menjadi tambahan sumber pemasukan bagi masyarakat.

\subsection{Dampak Penerapan Sapta Pesona Terhadap Kesejahteraan Masyarakat di Desa Watukarung}

Adanya Sapta Pesona di Desa Watukarung ini bertujuan untuk memaksimalkan potensi yang ada di Desa Watukarung, dengan tetap memperhatikan pelestarian lingkungan dan budaya. Penerapan Sapta Pesona ini diharapkan membawa pariwisata di Desa Watukarung ke arah yang lebih baik, dari segi sosial maupun dari segi ekonomi masyarakat di Desa Watukarung. Perkembangan wisata di Desa Watukarung juga dapat menciptakan lapangan kerja di sekitar Desa Watukarung sehingga dapat mengurangi jumlah pengangguran di Desa Watukarung. . Disamping menjadi mesin penggerak ekonomi, pariwisata juga merupakan wahana menarik untuk mengurangi angka pengangguran. Oleh sebab itu pembangunan wisata dapat dilakukan di daerah yang berpengaruh dalam menciptakan lapangan pekerjaan (Suwantoro, 2004).

Sebelum berkembangnya pariwisata di Desa Watukarung, masyarakat umumnya bergantung kepada hasil laut dan pertanian. Berkembangnya pariwisata di Desa Watukarung sendiri mendatangkan banyak berkah bagi masyarakat sekitar. Dari masyarakat yang berfokus menjadi nelayan, sekarang dapat mendapatkan alternatif penghasilan dari menjadi ojek kapal di wisata Sungai Cokel. Dari ibu-ibu yang terbiasa kesehariannya hari bertani, sekarang memiliki penghasilan dari berjualan makanan di warung di area sekitar wisata Desa Watukarung. Masyarakat yang tinggal berdekatan dengan lokasi wisata juga terkena dampak, masyarakat bisa mendirikan homestay di sekitar area wisata, sehingga dapat menambah penghasilan tambahan dari homestay tersebut. Anak muda yang tidak mampu merasakan pendidikan lebih lanjut mendapatkan pekerjaan dari dibukanya wisata baru seperti Pantai Kasap dan Sungai Cokel. Para pemuda bisa bekerja sebagai tukang parkir, petugas loket tiket masuk, dan menjadi operator wahana wisata. Maka dari itu, jika semua potensi yang ada di

Desa Watukarung dapat dimaksimalkan, tentu dapat membantu kesejahteraan dari 
masyarakat di Desa Watukarung. Sapta pesona diharapkan tetap menjadi acuan bagi masyarakat Desa Watukarung untuk mengembangkan potensi yang ada di di Desa Watukarung, tanpa acuan yang jelas dikhawatirkan perkembangan wisata ini malah akan merusak alam sekitar, Seperti yang dikemukakan Suwantoro (2004) bahwa pariwisata sering dituding sebagai penyebab kerusakan lingkungan.

\section{Simpulan}

Berdasarkan hasil penelitian dan data yang diperoleh dan sudah di analisis tentang penerapan Sapta Pesona dalam menciptakan masyarakat sadar wisata untuk meningkatkan kesejahteraan masyarakat (Studi Pada Desa Watukarung, Kecamatan Pringkuku, Kabupaten Pacitan) dapat ditarik kesimpulan sebagai berikut: (1) Berkembangnya wisata di kawasan Desa Watukarung sendiri tentu terjadi karena pengelolaan dari berbagai pihak dan partisipasi masyarakat yang cukup antusias dengan pengembangan wisata di Desa Watukarung yang tentunya Sapta Pesona menjadi acuan bagi pengelola wisata yang disini pokdarwis berperan sebagai mesin penggerak bagi masyarakat untuk proses pengembangan wisata. Setiap unsur dari Sapta Pesona yaitu aman, tertib, bersih, sejuk, indah, ramah, kenangan sudah sebagian besar diterapkan di kawasan wisata di Desa Watukarung, hanya memang ada beberapa aspek seperti kenangan yang masih bisa sangat ditingkatkan lagi oleh masyarakat di Desa Watukarung, seperti menyediakan cinderamata khas dari Desa Watukarung untuk wisatawan, sehingga ada kenangan yang bisa di beli oleh wisatawan untuk di bawa pulang. Jika masyarakat mampu memanfaatkan peluang itu, maka bisa menjadi tambahan penghasilan yang lain lagi untuk masyarakat di Desa Watukarung, (2) Melihat dari faktor kesejahteraan masyarakat, berkembangnya wisata di Desa Watukarung memberikan dampak bagi para pelaku usaha yang terlibat langsung di dalam pengembangan obyek wisata di Desa Watukarung. Peluang usaha terbuka setelah beberapa obyek wisata dikembangkan seperti Pantai Kasap dan Sungai Cokel. Masyarakat yang dulu hanya berprofesi menjadi petani dan nelayan setelah adanya obyek wisata baru yang dikembangkan mendapatkan opsi lain dalam mendapatkan hasil untuk meningkatkan kesejahteraan perekonomian keluarga. Selain itu wisata baru di buka memberikan lapangan pekerjaan baru bagi masyarakat di Desa Watukarung, sehingga dapat mengurangi pengangguran di Desa Watukarung.

Bagi masyarakat Desa Watukarung, diperlukan dorongan dari setiap golongan masyarakat di Desa Watukarung agar lebih berpartisipasi untuk ikut serta mengembangkan obyek wisata yang ada di Desa Watukarung dan disertai dengan pemahaman tentang Sapta Pesona yang lebih baik lagi, sehingga berkembangnya wisata di Desa Watukarung dapat dimaksimalkan. Masih banyak potensi wisata yang masih sangat bisa dioptimalkan oleh masyarakat di Desa Watukarung, dengan jajaran pantai yang terbang, akan sangat besar potensi pemikiran kreatif yang bisa di tuangkan. Dan jika berjalan dengan baik maka akan membuka sumber penghasilan lain bagi masyarakat di Desa Watukarung. Tentu perlu komitmen kuat dari semua anggota masyarakat Desa Watukarung untuk mewujudkan hal tersebut.

\section{Daftar Rujukan}

Amirullah. (2016). Penerapan Sapta Pesona di Pantai Polewali Kabupaten Polewali Mandar Provinsi Sulawesi Barat. Jurnal Kepariwisataan. 10(2) 15-27.

Astuti, D. S. I. (2012). Partisipasi Masyarakat dalam Desentralisasi Pendidikan: Penerapan Manajemen Berbasis Sekolah (MBS) dan Partisipasi Orang Tua dalam Peningkatan Mutu Pada Satuan Pendidikan. 
Jurnal Ekonomi, Bisnis dan Pendidikan, 1(2), 2021, 111-119

Aprilia, T. et al, (2014). Pembangunan Berbasis Masyarakat Acuan Bagi Praktisi, Akademi dan Pemerhati Pengembangan Masyarakat. Bandung: Alfabeta

Hakim, L. (2014). Enobotani dan Manajemen Kebun - Pekarangan Rumah: Ketahanan Pangan, Kesehatan, dan Agrowisata. Malang: Selaras

Adi, I. R. (2007). Perencanaan partisipatoris berbasis aset komunitas: dari pemikiran menuju penerapan. FISIP UI Press.

Khalik, W. (2014). Kajian Kenyamanan dan Keamanan Wisatawan di Kawasan Pariwisata Kuta Lombok. JUMPA. 1(1) $23-42$

Pariwisata, K. M. (1989). Pos dan Telekomunikasi No: KM. 5/UM (Vol. 424). 209/MPPT-89 tentang Pedoman Penyelenggaraan Sapta Pesona.

Nasikun. D (1996). Urbanisasi dan Kemiskinan di Dunia Ketiga. Yogyakarta: Tiara Wacana

Pariwisata, K., \& Kreatif, E. (2012). Pedoman kelompok sadar wisata. Jakarta: Kemenpar \&Ekraf.

Kebudayaan, M. (2010).Peraturan Menteri Kebudayaan dan Pariwisata Nomor: PM. 26/UM. 001/MKP/2010 tentang Pedoman Umum Program Nasional Pemberdayaan Masyarakat (PNPM) Mandiri Pariwisata melalui Desa Wisata.

Rahim, F. (2012). Pedoman Kelompok Sadar Wisata. Jakarta: Kementerian Pariwisata dan Ekonomi Kreatif.

Republik Indonesia. (2016). Undang-Undang Nomor 10 Tahun 2009 Tentang Kepariwisataan. Jakarta

Rencana Pembangunan Jangka Menengah Desa Watukarung 2018-2022. (2018).

Riawan, A., \& Indraphrasta, D. E. A. (2017). The Role of Sapta Pesona Wisata in Increasing the Revenue of Tourism Industry Entrepreneurs at the South Bantul Beaches. Khasanah Ilmu-Jurnal Pariwisata Dan Budaya, 8(2).

Suryadana. M. L \& Oktavia. V. (2015). Pengantar Pemasaran Ekonomi. Bandung: Alfabeta.

Stanford, D. (2006). Responsible Tourism Responsible Tourist: What Makes a Responsible Tourist in New Zealand. Victoria University of Wellington

Suyadi. (2015). Pengaruh program Sapta Pesona terhadap peningkatan pengunjung Obyek Wisata Guci Tegal. Jurnal Utilitas. 1(2): 157-169.

Suwena, I. K., Widyatmaja, I. G. N., \& Atmaja, M. J. (2010). Pengetahuan dasar ilmu pariwisata. Udayana University Press.

Suwantoro, G. (2004). Dasar-Dasar Pariwisata. Yogyakarta: Andi.

Bentley, T., Page, S., Meyer, D., Chalmers, D., \& Laird, I. (2001). How safe is adventure tourism in New Zealand? An exploratory analysis. Applied ergonomics, 32(4), 327-338.

UNWTO, U. (2005). Making Tourism More Sustainable-A Guide for Policy Makers. UNEP UNWTO: New York, NY, USA.

Yoeti, O. A. (2001). Ilmu Pariwisata: Sejarah. Perkembangan dan Prospeknya. Jakarta: Pertja 